\title{
Pengaruh Preprocessing Terhadap Klasifikasi Diabetic Retinopathy dengan Pendekatan Transfer Learning Convolutional Neural Network
}

\author{
http://dx.doi.org/10.28932/jutisi.v7i1.3327 \\ Riwayat Artikel \\ Received: 24 Januari 2021 | Final Revision: 25 Februari 2021 | Accepted: 4 Maret 2021 \\ Juan Elisha Widyaya ${ }^{\# 1}$, Setia Budi ${ }^{\bowtie * 2}$ \\ ${ }^{\#}$ Magister Ilmu Komputer, Universitas Kristen Maranatha \\ Jl. Prof. Drg. Surya Sumantri, MPH 65. Bandung \\ ${ }^{1}$ mi1979006estudent.it.maranatha.edu \\ ${ }^{2}$ setia.budieit. maranatha.edu
}

\begin{abstract}
Diabetic retinopathy (DR) is eye diseases caused by diabetic mellitus or sugar diseases. If DR is detected in early stages, the blindness that follows can be prevented. Ophthalmologists or eye clinicians usually decide the stage of DR from retinal fundus images. Careful examination of retinal fundus images is a time-consuming task and requires experienced clinicians or ophthalmologists but a computer which has been trained to recognize the DR stages can diagnose and give results in real-time manner. One approach of algorithms to train a computer to recognize an image is deep learning Convolutional Neural Network (CNN). CNN allows a computer to learn the features of an image, in our case is retinal fundus image, automatically. Preprocessing is usually done before a CNN model is trained. In this study, four preprocessing were carried out on "APTOS 2019 Blindness Detection" dataset. Of the four preprocessing tested, preprocessing with Contrast Limited Adaptive Histogram Equalization followed by unsharp masking on the green channel of the retinal fundus image give the best results with an accuracy of $78.79 \%, 82.97 \%$ precision, $74.64 \%$ recall, and $95.81 \%$ AUC. The CNN architecture used is Inception v3.
\end{abstract}

Keywords - classification; Convolutional Neural Network; Diabetic Retinopathy; Inception v3; transfer learning

\section{PENDAhuluan}

Diabetic Retinopathy (DR) atau yang dikenal juga sebagai Diabetic Eye Disease adalah penyakit mata akibat komplikasi diabetes yang merusak retina dan dapat mengakibatkan kebutaan [1]. DR merupakan penyakit progresif yang akan berkembang semakin parah seiring lamanya seorang pasien menderita DR. Deteksi DR sejak dini sangat penting agar pasien mendapatkan perawatan untuk mengurangi perkembangan DR dan mencegah kebutaan karena pada tahap tertentu DR tidak bisa disembuhkan lagi [2]. Diagnosis pasien DR biasanya dilakukan oleh ophthalmologist dengan memeriksa citra fundus retina secara seksama. Proses pemeriksaan seperti ini cukup memakan waktu [3]. Belum lagi perbandingan antara jumlah pasien potensial dan ketersediaan tenaga medis tidak seimbang, sehingga mendorong kebutuhan adanya sistem untuk membantu deteksi DR secara otomatis [2].

Deteksi DR pada citra fundus retina dapat dibagi menjadi dua tugas [2], 1) deteksi DR berdasarkan tingkat lesion dan 2) deteksi DR berdasarkan tingkat citra. Deteksi pada tingkat lesion artinya mendeteksi gejala klinis pada citra fundus retina, seperti tanda-tanda microaneurysm, hemorrhages, exudates, dan neovascular. Deteksi DR pada tingkat citra artinya deteksi DR pada citra fundus retina untuk menilai apakah terdapat tanda-tanda DR.

Deteksi pada tingkat citra mengklasifikasikan citra fundus ke dalam dua kategori, yaitu normal atau memiliki tandatanda DR. Citra fundus yang terdapat tanda-tanda DR dapat dibagi ke dalam dua kelas berdasarkan tingkat keparahannya 1) Non-Proliferative Diabetic Retinopathy (NPDR) dan 2) Proliferative Diabetic Retinopathy (PDR). NPDR adalah tahap awal di mana diabetes mulai merusak pembuluh darah kecil pada retina, hal ini umum ditemui pada penderita diabetes; di mana pembuluh darah mulai mengeluarkan cairan dan darah yang menyebabkan retina bengkak. Seiring berjalannya waktu, pembengkakan atau edema dapat menebalkan retina yang menyebabkan pandangan kabur. Fitur klinis pada tahap ini setidaknya terdapat satu microaneurysm atau hemorrhage baik tanpa atau dengan exudates [2].

PDR adalah tahapan lanjut yang mengarah ke pertumbuhan pembuluh darah baru. PDR ditandai dengan penyebaran pembuluh darah abnormal di dalam retina menuju rongga vitreous. Pembuluh darah baru ini bersifat rapuh dan dapat mengakibatkan pendarahan pada rongga vitreous yang menyebabkan kebutaan. Terdapat beberapa 
sistem untuk menilai tingkat keparahan DR, seperti American Academy of Ophthalmology (AAO), Early Treatment of Diabetic Retinopathy Study (ETDRS), dan protokol penilaian Scottish. Pada penelitian ini DR diklasifikasikan menjadi lima kelas yang mengacu pada protokol penilaian Scottish, yaitu tidak ada DR, DR ringan, DR sedang, DR parah, dan PDR. Contoh citra fundus retina dengan tingkat DR yang berbeda dapat dilihat pada Gambar 1. Gambar kiri-atas dengan label DR-0 adalah citra fundus retina tidak ada DR, atau citra fundus retina normal. Gambar kanan-bawah dengan label DR-4 adalah citra fundus retina PDR.

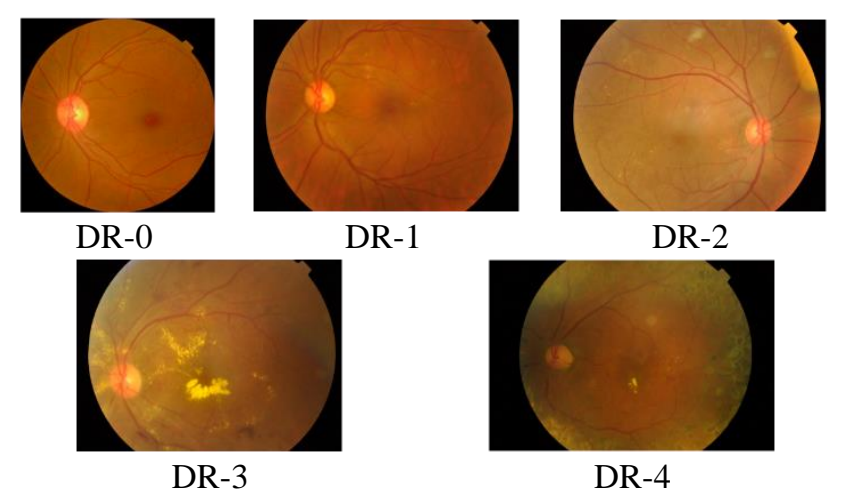

Gambar 1. Citra fundus retina dengan tingkat DR yang berbeda

Berbagai upaya dilakukan untuk mendeteksi dan mengklasifikasikan citra fundus retina dengan bantuan komputer atau Computer Aided Diagnosis (CAD) [2]. Salah satu pendekatan untuk mengklasifikasikan DR pada citra fundus retina adalah dengan pendekatan deep learning Convolutional Neural Network (CNN). CNN berkembang pesat dan banyak digunakan untuk tugas klasifikasi citra sejak kompetisi ImageNet pada tahun 2012 yang dimenangkan oleh Alex Krizhevsky dan kawan-kawan [4]. Mereka membawa revolusi CNN melalui penggunaan Graphics Processing Unit (GPU), Rectified Linear Units (ReLU), regularisasi dropout, dan augmentasi data yang efektif [5].

Training model CNN dapat dilakukan dengan salah satu dari dua pendekatan, yaitu end to end learning atau transfer learning. Training model dengan pendekatan end to end learning memiliki tantangan sendiri [5], yaitu membutuhkan jumlah data yang besar. Namun jumlah data yang besar tidak selalu dijumpai pada domain citra medis. Jika terdapat dataset dalam jumlah yang besar, permasalahan berikutnya muncul, yaitu kebutuhan akan sumber daya komputasi yang besar. Selain itu, training model CNN juga sering kali sulit karena overfitting atau masalah konvergensi model sehingga dibutuhkan penyesuaian hyperparameter model berulang kali.

Salah satu pendekatan alternatif adalah training model CNN dengan pendekatan transfer learning. Pendekatan transfer learning menggunakan model yang sudah ditraining pada domain dataset tertentu (umumnya dataset ImageNet [6]) lalu disesuaikan (fine-tuned) pada domain dataset baru (dataset citra fundus retina). Menurut Yosinski dan kawan-kawan [7], dan Nima Tajbakhsh dan kawankawan [5], pendekatan transfer learning cenderung memberikan hasil yang lebih baik jika dibandingkan dengan pendekatan end to end learning.

Sebelum model CNN di-training, biasanya akan dilakukan preprocessing terhadap citra fundus retina untuk mengatasi beberapa tantangan pada pengolahan citra digital seperti variasi skala, variasi iluminasi, atau gambar tidak fokus. Dari tinjauan pustaka yang dilakukan, tidak banyak yang membahas pengaruh preprocessing terhadap performa model. Penelitian ini membandingkan pengaruh preprocessing terhadap performa model diantaranya adalah Maria A. Bravo [8] dan Chunyan Lian [9]. Dari tinjauan pustaka juga dapat dilihat bahwa pendekatan transfer learning lebih banyak digunakan jika dibandingkan dengan end to end learning. Hal ini umum dilakukan karena keterbatasan jumlah citra untuk training model CNN menjadi salah satu tantangan di bidang citra medis [5]. Namun fine tuning pada pendekatan transfer learning tersebut tidak membahas berapa banyak lapisan dari arsitektur CNN yang perlu di-fine tuning. Salah satu penelitian yang menyampaikan hal ini adalah penelitian yang dilakukan oleh Saboora dan kawan-kawan [10]. Saboora melakukan fine tuning sebanyak dua dan empat blok pada arsitektur Inception v3 dan Xception untuk klasifikasi biner citra fundus retina.

Sesuai dengan latar belakang yang disampaikan, maka penelitian ini menguji pengaruh preprocessing terhadap performa model dan menguji banyaknya blok Inception v3 yang perlu di-fine tuning. Tugas klasifikasi yang diberikan adalah mengklasifikasikan citra fundus retina ke dalam lima kelas. Sehingga terdapat dua pertanyaan yang dijawab pada penelitian ini, yaitu:

- Apa pengaruh preprocessing terhadap hasil training model dengan pendekatan transfer learning?

- Berapa banyak blok Inception v3 dari sebuah model yang di-training dengan pendekatan transfer learning perlu di-fine tuning?

Diharapkan dari penelitian ini bisa memberikan jawaban atas dua rumusan masalah diatas, yaitu:

- Mengetahui pengaruh preprocessing yang diterapkan pada citra fundus retina terhadap performa model yang dihasilkan.

- Mengetahui jumlah blok Inception v3 yang perlu difine tuning ketika training model dengan pendekatan transfer learning untuk tugas klasifikasi citra fundus retina.

Penelitian ini membangun model untuk mengklasifikasikan citra fundus retina menjadi lima kelas, mulai dari kelas tidak ada DR, DR ringan, DR sedang, DR parah, dan PDR dengan teknik CNN. Arsitektur CNN yang dipakai adalah Inception v3 [11]. Dataset yang digunakan adalah citra fundus retina yang diambil dari Kaggle.com [12]. Dataset ini merupakan dataset untuk kompetisi pada Kaggle 
dengan judul “APTOS 2019 Blindness Detection”. Penelitian ini fokus untuk melihat pengaruh preprocessing terhadap model yang dihasilkan dan melihat jumlah blok Inception v3 yang perlu di-fine tuning dengan pendekatan transfer learning.

Penelitian ini mengemukakan dua hipotesis sebagai berikut:

- Preprocessing yang tepat akan memberikan dampak positif terhadap performa model. Dengan preprocessing diharapkan fitur yang diinginkan pada citra menjadi lebih menonjol.

- Fine tuning perlu dilakukan pada beberapa blok terakhir saja dari model yang di-training dengan pendekatan transfer learning. Pada lapisan awal, fine tuning tidak memberikan pengaruh terhadap performa model karena pada lapisan awal CNN mengekstrak fitur umum dari citra.

\section{LANDASAN TEORI}

Convolutional Neural Network (CNN) adalah Neural Network (NN) khusus untuk memproses data yang memiliki topologi berbentuk grid [13]. Data time series adalah data dengan topologi satu dimensi dan citra adalah data dengan topologi dua dimensi. Nama Convolutional Neural Network mengindikasikan bahwa Neural Network melakukan proses operasi matematika convolution yang merupakan operasi linear. Convolutional Neural Network secara sederhana adalah Neural Network yang menggunakan convolution sebagai operasi multiplikasi matrix setidaknya pada salah satu lapisan. CNN terdiri dari lapisan convolution dan pooling yang memungkinkan fitur diekstrak dari citra.

\section{A. Convolutional Neural Network}

CNN mengekstrak fitur dari citra dengan melakukan operasi convolution antara kernel dengan input tensor yang merupakan subset array pixel [14]. Perubahan posisi kernel secara berturut-turut dikenal dengan istilah strides. Stride lebih dari satu memberikan efek downsampling pada output operasi convolution. Produk perkalian element wise dari setiap subset array pixel dan kernel akan dijumlahkan untuk menghasilkan satu nilai numerik dalam feature map. Feature map ini diteruskan ke fungsi aktivasi, yang biasanya menggunakan fungsi aktivasi Rectified Linear Unit (ReLU) sebelum diteruskan ke lapisan pooling. Lapisan pooling melakukan downsample terhadap feature map untuk mengurangi kebutuhan daya komputasi dan mencegah overfitting. Operasi pooling yang digunakan umumnya adalah max pooling. Max pooling menghasilkan output sama dengan nilai maksimum dari setiap patch data pada feature map. Max pooling dengan kernel $2 \times 2$ dan stride 2 akan mengambil satu nilai maksimum dari setiap empat feature map. Sekuensial dari convolution, kernel, dan pooling menghasilkan sejumlah lapisan data atau fitur yang di bagian akhir lapisan akan ditransformasi menjadi array satu dimensi. Proses transformasi ini disebut dengan istilah flattening.

Gambar 2 adalah contoh operasi CNN. CNN memiliki sejumlah lapisan convolutional dan pooling yang menghasilkan feature map sebelum tahap flattening dan masuk ke Neural Network untuk klasifikasi. Pada gambar tersebut input adalah tensor dua dimensi $6 \times 6$ dan convolutional menggunakan kernel $3 \times 3$ yang berjalan secara sekuensial dengan stride 1 . Operasi convolution menghasilkan feature map berukuran $4 \times 4$. Lapisan max pooling menggunakan kernel berukuran $2 \times 2$ dengan stride 2 yang mengambil satu nilai maksimum dari empat elemen terkait (patch) sebagai representasi data. Operasi max pooling menghasilkan pooled feature map berukuran $2 \times 2$. Pooled feature map kemudian diubah dari dua dimensi menjadi satu dimensi (flattened) sebelum masuk ke Neural Network [14].

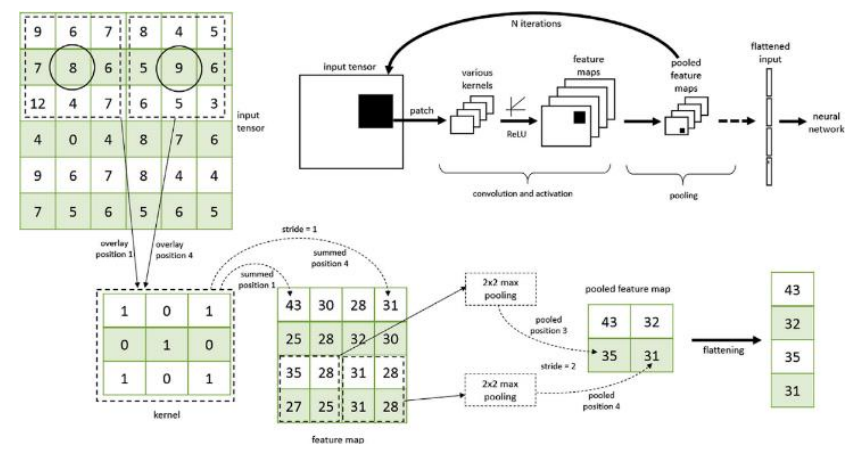

Gambar 2. Proses Convolutional Neural Network [14]

\section{B. Inception $v 3$}

Arsitektur Inception v1 dari GoogLeNet didesain untuk bekerja dengan baik dengan kondisi komputasi yang terbatas [15]. Hal ini dicapai dengan melakukan penggabungan output dari kernel convolution berukuran $1 \times 1,3 \times 3,5 \times 5$ dan pooling sambil menjaga tinggi dan lebar output dari setiap kernel tidak berubah [15], [16]. Lapisan bottleneck atau operasi convolution $1 \times 1$ selalu dilakukan sebelum operasi convolution $3 \times 3$ dan $5 \times 5$ untuk mengurangi jumlah operasi matematika sampai dengan faktor 10. Arsitektur ini dikembangkan lebih lanjut oleh Christian Szegedy dan kawan-kawan [11] menjadi Inception v3.

Arsitektur Inception v3 [11] memanfaatkan teknik faktorisasi convolution asimetris untuk mengurangi jumlah operasi matematika. Modul Inception v3 terdiri atas tiga desain yaitu [17]: 


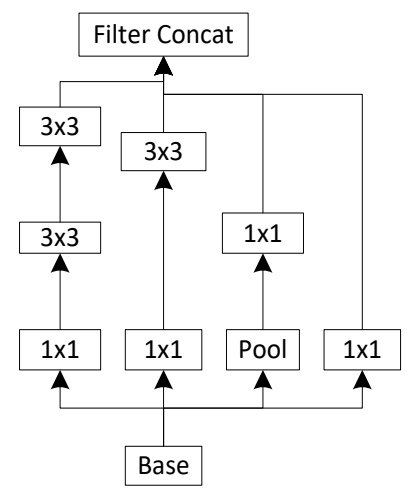

Modul A

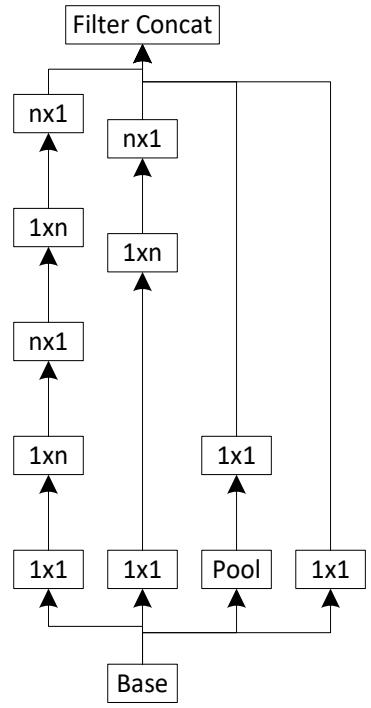

Modul B

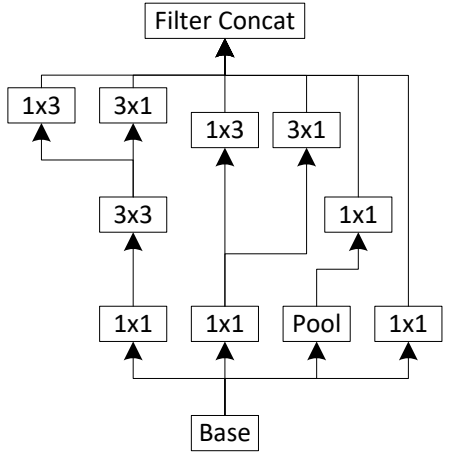

Modul C

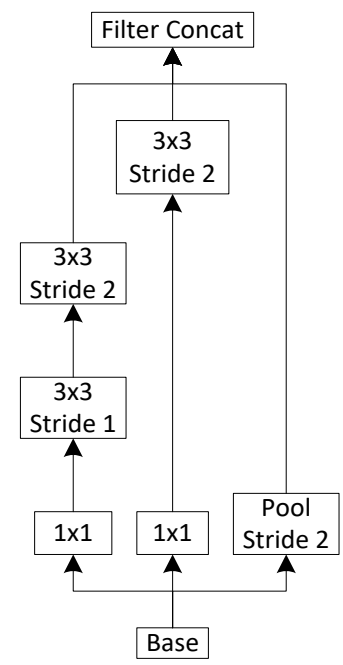

Grid Size Reduction

Gambar 3. Modul arsitektur Inception v3 [11]

- Modul Inception A (Gambar 3 Modul A): modul ini mengganti convolution $5 \times 5$ pada Inception v1 dengan dua buah convolution $3 \times 3$. Jika ditinjau dari total operasi matematika, convolution $5 \times 5$ membutuhkan 25 operasi matematika, sedangkan dua buah convolution $3 \times 3$ membutuhkan 18 operasi matematika.

- Modul Inception B (Gambar 3 Modul B): modul ini menggunakan teknik convolution asimetris $1 \times 7$ dan $7 \times 1$ sebagai ganti convolution $7 \times 7$.

- Modul Inception C (Gambar 3 Modul C): modul ini diajukan untuk mempromosikan representasi dimensi tinggi.

Inception v3 menawarkan langkah paralel (Gambar 3 Grid Size Reduction) yang menggabungkan operasi convolution dan operasi pooling untuk mendapatkan jumlah feature map yang sama dengan operasi convolution diikuti pooling atau pun sebaliknya namun Grid Size Reduction memiliki beban komputasi yang lebih ringan.

Secara umum arsitektur Inception v3 dapat dibagi menjadi dua bagian besar, yaitu bagian convolution dan bagian classifier yang digambarkan pada Gambar 15. Bagian convolution adalah kumpulan dari lapisan convolution, pooling, aktivasi ReLU, dan Batch Normalization yang akan mengekstrak fitur dari citra input. Bagian classifier tersusun atas Neural Network yang bertugas mengklasifikasikan fitur yang sudah diekstrak oleh bagian convolution.

\section{Transfer Learning}

Ketika training model dengan pendekatan transfer learning, bagian classifier dari pretrained model perlu diganti dengan classifier baru. Classifier yang ditambahkan pada bagian akhir CNN di-training terlebih dahulu sementara bobot pada bagian convolution akan dibekukan. Setelah classifier konvergen, fine tuning dapat dilakukan pada bagian convolution. Menurut Yosinski dan kawan-kawan [7], fine tuning dari lapisan manapun pada bagian convolution memberikan benefit terhadap performa model.

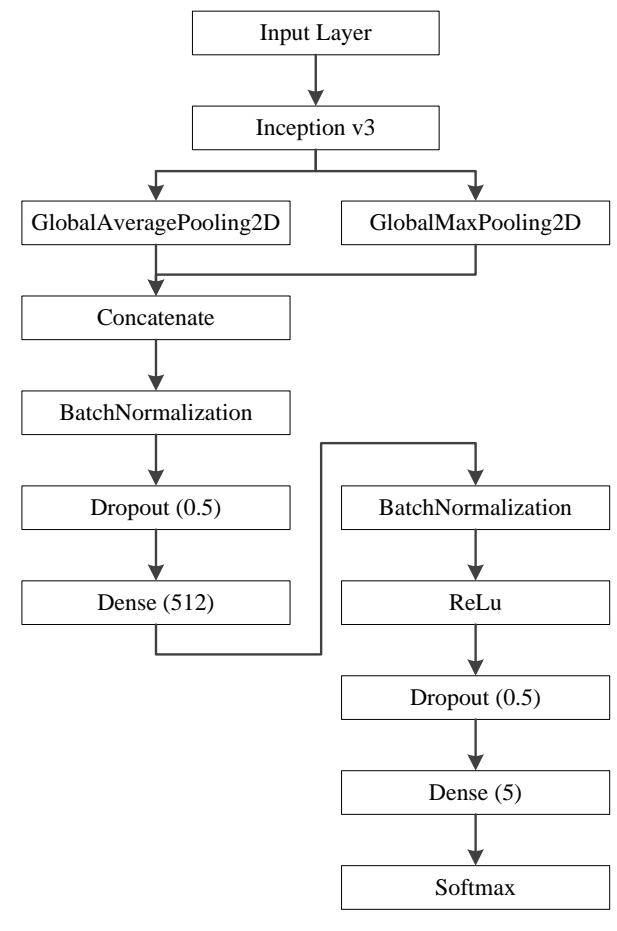

Gambar 4. Arsitektur classifier yang dimodifikasi

Arsitektur yang ditambahkan pada bagian akhir CNN dapat dilihat pada Gambar 4. Arsitektur ini terinspirasi dari Fastai namun dimodifikasi pada posisi BatchNormalization dan Relu. Pada Fastai [18], BatchNormalization diletakkan setelah lapisan aktivasi Relu. Namun menurut Andrew Ng 
[19], BatchNormalization umumnya diletakkan sebelum lapisan aktivasi ReLU.

\section{Penelitian Terkait}

Berbagai penelitian sudah dilakukan untuk membangun model menggunakan komputer untuk mendiagnosis DR secara otomatis [2]. Metode tradisional machine learning akan mengekstrak fitur dari citra fundus retina. Fitur yang sudah diekstrak tersebut menjadi input bagi classifier tertentu seperti random forest, support vector machine, atau AdaBoost classifier [20]. Salah satu prasyarat teknik hand engineered feature adalah memahami gejala klinis DR secara mendalam untuk memilih fitur yang tepat. Berbeda dengan deep learning seperti CNN yang akan mengekstrak fitur secara otomatis dari citra [21]. Jika dibandingkan dengan hand engineered feature, teknik deep learning secara umum memberikan hasil yang lebih unggul [2].

Maria A. Bravo dan Pablo A. Arbelaez [8] menggunakan dataset dari EyePACS untuk mengklasifikasikan DR ke dalam lima kelas. Preprocessing yang dilakukan adalah:

- Circle RGB: citra fundus retina RGB yang dipotong melingkar dengan ukuran $224 \times 224$ pixel.

- Square: citra fundus retina yang dipotong bujur sangkar dengan ukuran $224 \times 224$ pixel.

- Color centered: citra circle RGB dikurangi dengan warna rata-rata lokal menggunakan filter Gaussian. Intensitas setiap channel citra dipusatkan pada 127.

- Grayscale: citra circle RGB dikonversi menjadi citra grayscale.

TABEL I

HASIl PercobaAn Maria A. Bravo

\begin{tabular}{|l|l|l|}
\hline Preprocessing & VGG-16 & Inception V4 \\
\hline Circle RGB & $46.3 \%$ & $44.62 \%$ \\
\hline Square & $45.3 \%$ & \\
\hline Color centered & $48.3 \%$ & $45.00 \%$ \\
\hline Grayscale & $48.1 \%$ & \\
\hline
\end{tabular}

Arsitektur CNN yang digunakan adalah VGG-16 dan Inception v4. Kedua arsitektur ini di-training dengan pendekatan transfer learning. Model VGG-16 di-training kira-kira sebanyak 14 epoch, learning rate 0.001 yang diubah setiap 5 epoch dengan faktor 10, batch size 115, optimasi stochastic gradient descent with momentum (SGDM) (momentum $=0.9)$, dan regularisasi dropout untuk mengurangi overfitting. Sedangkan model Inception v4 ditraining sebanyak 20 epoch, batch size 32, learning rate 0.001 , dan regularisasi weight decay 0.00004. Selama training model, baik arsitektur VGG-16 maupun arsitektur Inception v4, dilakukan augmentasi citra dengan rotasi antara $0^{\circ}$ sampai dengan $360^{\circ}$, perbesar dan perkecil gambar antara 0 sampai dengan 20 pixel, pembalik vertikal dan horizontal yang dilakukan secara acak. Hasil percobaan ini bisa dilihat pada Tabel I.

Saboora Mohammadian dan kawan-kawan [10] menggunakan dataset EyePACS untuk mengklasfikasikan
DR ke dalam dua kelas. Preprocessing yang dilakukan adalah mengubah ukuran citra agar memiliki ukuran yang sama, nilai setiap pixel dikurangi dengan nilai rata-rata lokal, lalu citra dipetakan terhadap 50\% abu-abu sehingga ketajaman citra lebih merata. Pinggiran dari citra retina dipotong untuk menghilangkan efek garis batas. Arsitektur yang dipilih adalah Inception v3 dan Xception yang di-training dengan pendekatan transfer learning. Model di-training sebanyak 200 iterasi dengan nilai learning rate 0.0001. Augmentasi yang digunakan adalah pergeseran citra, rotasi citra, pembalikan citra vertikal dan horizontal selama training. Saboora membandingkan beberapa parameter training untuk melihat pengaruhnya terhadap performa model yang dihasilkan. Parameter yang dibandingkan adalah optimasi Adaptive Moment Estimation (ADAM) dengan SGDM (momentum $=0.9)$, aktivasi Exponential Linear Unit $(\mathrm{ELU})$ dengan ReLU, dan dua blok dengan empat blok yang di-fine tuning. Hasil terbaik dengan nilai akurasi $87.12 \%$ diperoleh dari model Inception v3, optimasi ADAM, dan fine tuning sebanyak dua blok.

Gabriel Garcia dan kawan-kawan [22] menggunakan dataset EyePACS untuk mengklasifikasikan DR ke dalam dua kelas. Preprocessing yang dilakukan adalah mengubah ukuran citra sehingga memiliki ukuran yang sama, citra dikurangi dengan nilai rata-rata lokal, lalu dipetakan ke abuabu. Setelah preprocessing tersebut, citra diskalakan menjadi $256 \times 256$ pixel. Augmentasi yang dilakukan adalah flipping citra dan cropping $80 \%$ citra. Gabriel Garcia menggunakan arsitektur VGG-16 yang di-training dengan pendekatan transfer learning. Karena jumlah citra dari masing-masing tidak seimbang, Gabriel menggunakan class weight dengan perbandingan untuk kelas normal dan DR sebesar 1:2.74. Model VGG di-training dengan regularisasi weight decay 0.00005. Performa model yang diperoleh adalah akurasi $83.68 \%$, sensitivity $54.47 \%$, specificity $93.65 \%$.

Xiaoliang Wang dan kawan-kawan [16] menggunakan dataset dari EyePACS yang dipilih 166 citra saja untuk mengklasifikasikan DR ke dalam lima kelas. Preprocessing yang dilakukan mengubah ukuran citra menjadi $227 \times 227$ untuk AlexNet, $224 \times 224$ untuk VGG-16, dan $299 \times 299$ untuk Inception v3. Ketiga arsitektur ini di-training dengan pendekatan transfer learning. Parameter training yang digunakan adalah: optimasi SGDM (momentum = 0.9), fungsi aktivasi ReLU, dan beberapa parameter lain yang berbeda untuk setiap arsitektur. Hasil akurasi yang diperoleh adalah $37.43 \%$ untuk AlexNet, 50.03\% untuk VGG-16, dan $63.23 \%$ untuk Inception v3.

Chunyan Lian dan kawan-kawan [9] menggunakan dataset EyePACS untuk mengklasifikasikan DR ke dalam lima kelas. Preprocessing yang mereka lakukan adalah mengubah citra menjadi $256 \times 256$ pixel, meningkatkan warna citra dengan mengurangi warna rata-rata lokal, dan membuang warna latar hitam. Pada dataset dilakukan subsampling dan augmentasi untuk mengatasi persoalan dataset yang tidak seimbang. Terdapat tiga arsitektur yang dicoba, yaitu AlexNet, ResNet- 
50, dan VGG-16. Ketiga arsitektur ini di-training dengan pendekatan transfer learning. Parameter yang digunakan selama training adalah: learning rate 0.001 yang berkurang dengan faktor 10 setiap 27 epoch, batch size 25, optimasi SGDM (momentum $=0.9$ ), dan weight decay 0.0005. Hasil akurasi yang diperoleh pada penelitian ini adalah $73.19 \%$ untuk AlexNet, 76.41\% untuk ResNet-50, 79.04\% untuk VGG-16 dengan preprocessing, dan $76.01 \%$ untuk model VGG-16 tanpa preprocessing.

Zhentao Gao dan kawan-kawan [20] menggunakan dataset yang dibangun sendiri dengan total 4,476 citra untuk mengklasifikasikan DR menurut perawatan yang disarankan. DR diklasifikasikan ke dalam empat kelas, dari normal, sedang, berat, dan parah. Preprocessing yang dilakukan adalah mentransformasi citra, sehingga setiap citra memiliki ukuran dan bentuk yang sama, dan melakukan normalisasi warna. Augmentasi citra selama training adalah pembalikan citra horizontal dan vertikal, rotasi citra antara $\left[-25^{\circ}, 25^{\circ}\right]$ secara acak, pembesaran citra antara $[0.85,1.15]$, dan distorsi citra secara acak. Terdapat lima arsitektur yang dicoba pada penelitian Zhentao Gao, yaitu ResNet-18, Resnet-101, VGG19, Inception v3, dan arsitektur Inception@4 yang merupakan modifikasi dari Inception v3. Beberapa parameter yang digunakan untuk training model adalah: batch size 32, optimasi ADAM, learning rate 0.00001, weight decay 0.2, dan aktivasi ReLU. Akurasi yang diperoleh adalah $87.61 \%$ untuk ResNet-18, 87.26\% untuk ResNet-101, 85.50\% untuk VGG-19, 88.35\% untuk Inception v3, dan $88.72 \%$ untuk Inception@4.

Misgina Tsighe Hagos dan kawan-kawan [23] menggunakan dataset EyePACS untuk mengklasifikasikan DR ke dalam dua kelas. Jumlah dataset yang digunakan terdiri dari 2,500 citra training dan 5,000 citra validation. Preprocessing yang mereka lakukan adalah membuang warna latar hitam, mengubah citra menjadi $300 \times 300$ pixel, dan mengurangi warna rata-rata lokal dari setiap pixel. Arsitektur CNN yang digunakan adalah Inception v3 yang ditraining dengan pendekatan transfer learning. Parameter yang dipakai selama training adalah: optimasi SGD dengan ascending learning rate 0.0005 , fungsi loss cosine, dan fungsi aktivasi ReLU. Hasil akurasi yang diperoleh adalah $90.9 \%$.

Md Sazzad Hossen dan kawan-kawan [1] menggunakan dataset APTOS-2019 untuk mengklasifikasikan DR ke dalam lima kelas. Preprocessing yang mereka lakukan adalah mengubah skala citra sehingga memiliki radius yang sama, mengurangi warna rata-rata lokal yang dipetakan ke $50 \%$ grayscale, memotong citra menjadi ukuran $90 \%$. Ukuran citra yang digunakan untuk training adalah $224 \times 224$ pixel. Arsitektur CNN yang dipilih adalah DenseNet-121 dan ditraining dengan pendekatan transfer learning. Selama training mereka melakukan augmentasi dengan flipping horizontal dan vertikal secara acak dan pembesaran antara $85 \%$ sampai dengan $115 \%$ secara acak. Parameter training yang digunakan adalah: optimasi ADAM, total epoch 12, regularisasi dropout, dan fungsi aktivasi ReLU. Hasil yang didapatkan dari dataset validation adalah akurasi 0.9491, precision 0.9598, recall 0.9256, F-score 0.9395, dan AUC 0.9852 .

\section{Metodologi PENELITIAN}

Secara umum penelitian ini mengklasifikasikan citra fundus retina ke dalam lima kelas berdasarkan tingkatannya. Citra fundus retina tersebut diklasifikasikan ke dalam salah satu kelas: DR-0, DR-1, DR-2, DR-3, dan DR-4. Penelitian ini mengimplementasi teknik deep learning CNN yang mengekstrak fitur secara otomatis dari sebuah citra. Arsitektur CNN yang digunakan adalah Inception v3 dengan modifikasi pada bagian classifier seperti pada Gambar 4 .

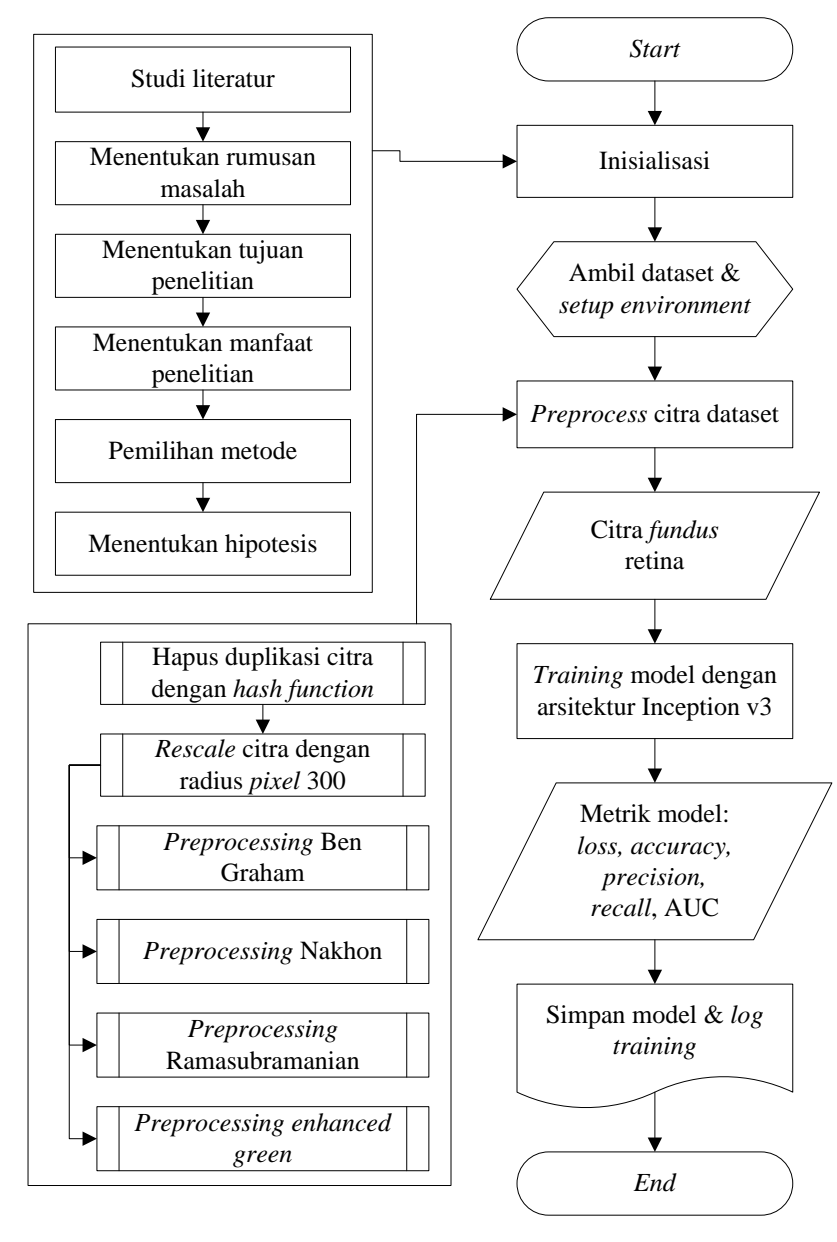

Gambar 5. Diagram alir penelitian

\section{A. Pipeline Penelitian}

Pipeline penelitian ini dapat dilihat pada Gambar 5. Penelitian diawali dengan studi literatur, menentukan rumusan masalah, tujuan penelitian, pemilihan metode, dan hipotesis yang diuji. Eksperimen diawali dengan membuang duplikasi citra dalam dataset [24], lalu semua citra diubah ukurannya sehingga memiliki radius pixel 300 pada wilayah retina [25]. Citra yang sudah diubah ukurannya ini 
dilanjutkan dengan empat preprocessing terpisah, yaitu preprocessing Ben Graham [25], Nakhon [26], Ramasubramanian [27], dan enhanced green.

Setelah preprocessing, dilakukan training model dengan menggunakan teknik deep learning CNN. Training model dilakukan dengan pendekatan transfer learning menggunakan beberapa kondisi dataset, yaitu:

- Citra tanpa preprocessing hanya dilakukan rescale.

- Citra dengan preprocessing Ben Graham [25].

- Citra dengan preprocessing Nakhon Ratchasima [26].

- Citra dengan preprocessing Ramasubramanian [27]

- Citra dengan preprocessing enhanced green.

- Citra tanpa preprocessing hanya dilakukan rescale lalu di-fine tuning sebanyak $n$ blok Inception v3, $\mathrm{n}=[1$, $2, \ldots, 10]$ dan semua lapisan.

Pada bagian akhir training, model dievaluasi berdasarkan metrik loss, akurasi, precision, recall, dan AUC. Meskipun terdapat beberapa metrik yang digunakan, metrik akurasi dipilih sebagai metrik utama untuk mengukur performa model.

\section{B. Dataset}

Dataset yang digunakan untuk training model diambil dari dari Kaggle.com [12]. Dataset ini berasal dari rumah sakit mata Aravind Eye Hospital [13] yang dikeluarkan bersamaan dengan kegiatan APTOS Symposium ke-4 [28]. Dataset APTOS 2019 ini diberikan kepada publik dengan tujuan untuk meningkatkan kemampuan rumah sakit mengidentifikasi tingkatan DR dengan bantuan teknologi dan dapat memberikan hasil yang konsisten atau robust dengan berbagai kondisi dan variasi citra input. Dataset merupakan fotografi fundus retina dalam berbagai kondisi yang telah diberi label terhadap setiap citra dengan skala 0 sampai 4 oleh ahli klinis seperti yang dapat dilihat pada Tabel II.

TABEL II

LABEL UNTUK CITRA SESUAI DENGAN TINGKAT DR

\begin{tabular}{|l|l|l|c|}
\hline Label & Label one hot & \multicolumn{1}{|c|}{ Indikasi } & Jumlah citra \\
\hline 0 & {$[1,0,0,0,0]$} & Tidak ada DR & 1,805 \\
\hline 1 & {$[0,1,0,0,0]$} & DR rendah & 370 \\
\hline 2 & {$[0,0,1,0,0]$} & DR sedang & 999 \\
\hline 3 & {$[0,0,0,1,0]$} & DR parah & 193 \\
\hline 4 & {$[0,0,0,0,1]$} & DR proliferative & 270 \\
\hline \multicolumn{3}{|c|}{ Total citra } & $\mathbf{3 , 6 6 2}$ \\
\hline
\end{tabular}

Kumpulan citra dalam dataset ini merupakan citra sebagaimana adanya ketika diambil yaitu terdapat noise pada citra dan label. Di antara citra terdapat objek asing, tidak fokus, kurang cahaya atau kelebihan cahaya. Citra ini juga diambil dari berbagai klinik menggunakan beragam kamera di waktu yang berbeda sehingga memberikan variasi yang tinggi terhadap kumpulan citra. Contoh dataset dapat dilihat pada Gambar 6. Pada gambar tersebut dapat terlihat citra fundus retina dengan labelnya yang encoded dalam bentuk one hot vector.
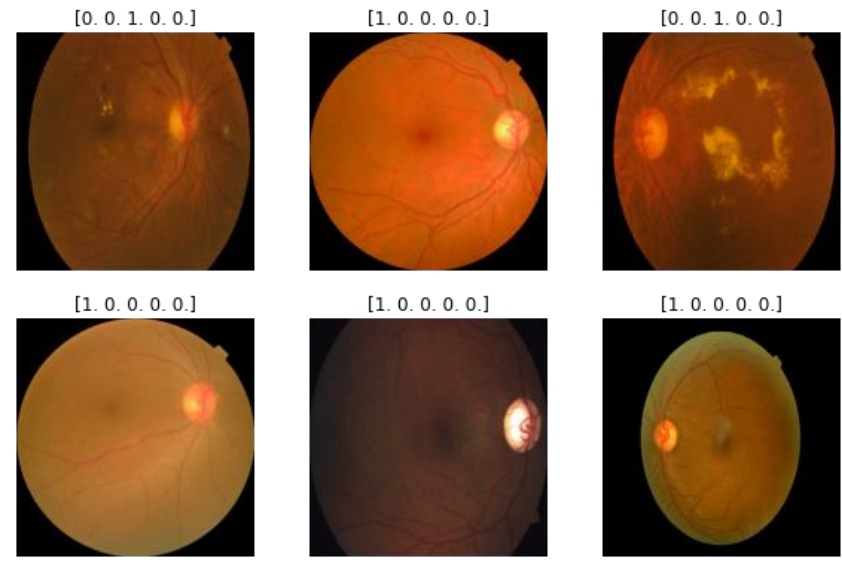

Gambar 6. Contoh citra fundus retina beserta dengan labelnya.

Deskripsi dataset adalah sebagai berikut:

- File format citra: PNG

- Variasi dimensi citra: $474 \times 358$ pixel $-3,388 \times$ 2,588 pixel

- Variasi ukuran file citra: $217 \mathrm{kB}-7,495 \mathrm{kB}$

- Jumlah citra training: 3,662 citra

\section{Preprocessing Dataset}

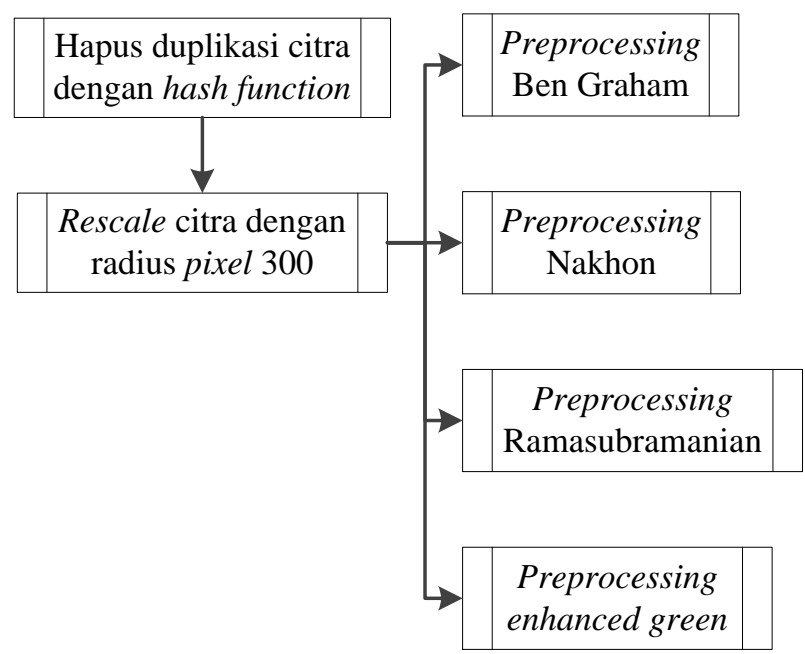

Gambar 7. Diagram alir preprocessing

Preprocessing diawali dengan memeriksa apakah terdapat duplikasi citra dalam dataset. Citra yang memiliki duplikasi akan dieliminasi dari dataset. Dataset yang sudah bersih dari duplikasi akan diubah ukurannya sehingga memiliki radius pixel yang sama untuk area retina pada citra. Berdasarkan tinjauan pustaka, preprocessing yang umum digunakan pada citra fundus retina merujuk pada preprocessing Ben Graham. Selain preprocessing tersebut terdapat preprocessing yang ditawarkan oleh Nakhon Ratchasima [26], yang merupakan notebook preprocessing dengan vote terbanyak pada Kaggle kompetisi dengan judul "APTOS 2019 Blindness Detection". Ramasubramanian [27] juga mengemukakan teknik preprocessing dengan menggunakan channel hijau saja. Preprocessing Ramasubramanian menjadi dasar inspirasi 
untuk preprocessing enhanced green. Sehingga terdapat empat preprocessing yang diterapkan kepada dataset dan diuji pengaruhnya terhadap performa model, yaitu preprocessing Ben Graham [25], Nakhon [26], Ramasubramanian [27], dan enhanced green. Hubungan preprocessing yang satu dengan yang lain dapat dilihat pada Gambar 7.

\section{1) Menghapus Duplikasi Citra}

Sebelum masuk ke tahap preprocessing, dataset diperiksa terlebih dahulu, apakah terdapat duplikasi citra. Algoritma difference hash (dhash) digunakan untuk memberikan signature atau identitas pada setiap gambar [24]. Dari signature tersebut dapat ditemukan duplikasi jika terdapat dua citra dengan signature yang sama. Signature diperoleh dengan mengambil $n$ digit bilangan biner dari sebuah citra. Langkah untuk membuat signature dengan algoritma dhash adalah:

- Konversi citra RGB menjadi citra grayscale.

- Mengubah ukuran citra menjadi ukuran $(n+1) \times n$ (column $\times$ row $)$.

- Periksa apakah nilai pixel ke $i>i+1$ dalam satu baris citra sehingga menghasilkan $n-1$ perbedaan antara pixel yang bersebelahan. $n$ baris dengan $n$ nilai perbedaan menghasilkan $n^{2}$ deret bilangan biner.

- Deret biner True / False (1 atau 0) tersebut dikonversikan menjadi integer berbentuk desimal yang dirumuskan dengan:

$$
\text { signature }=\sum_{i=0}^{n-1} d_{i} \times 2^{i}
$$

Di mana:

- $d_{i}$ adalah nilai 1 atau 0 dari deret biner ke - $i$

Pada penelitian ini $n$ yang dipakai adalah 32, sehingga diperoleh 1,024-bit nilai hash yang dikonversi ke bilangan integer. Nilai integer tersebut yang menjadi signature dari sebuah citra. Citra duplikasi dieliminasi dari dataset dengan ketentuan sebagai berikut:

- Jika terdapat dua citra atau lebih dengan signature yang sama dan label yang sama, maka diambil satu citra saja.

- Jika terdapat dua citra atau lebih dengan signature yang sama dan label yang berbeda, maka citra dikeluarkan dari dataset.

Pada Gambar 8 dapat dilihat duplikasi citra sebanyak tiga buah dengan label yang berbeda. Citra dengan kondisi seperti ini dieliminasi semuanya dari dataset. Label terletak di bagian atas citra.
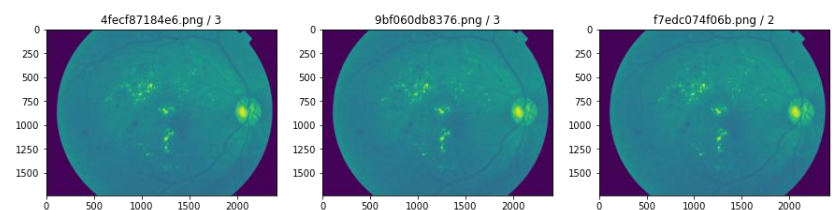

Gambar 8. Contoh gambar duplikasi dengan label yang berbeda.

Setelah citra dibersihkan dari duplikasi, maka diperoleh jumlah citra yang digunakan adalah 3,498 seperti yang dapat dilihat pada Tabel III.

TABEL III

Jumlah CitRa SEBElum DAN SETElah MENGHAPUS DuPliKasi

\begin{tabular}{|l|c|c|c|}
\hline Tingkat DR & Sebelum & Setelah & Komposisi Setelah \\
\hline 0 & 1,805 & 1,796 & $51.3 \%$ \\
\hline 1 & 370 & 338 & $9.7 \%$ \\
\hline 2 & 999 & 921 & $26.3 \%$ \\
\hline 3 & 193 & 173 & $4.9 \%$ \\
\hline 4 & 270 & 270 & $7.7 \%$ \\
\hline Total & 3,662 & 3,498 & \\
\hline
\end{tabular}

Dari Tabel III dapat dilihat bahwa kelas 0 memiliki komposisi citra sebanyak $51.3 \%$ dari total dataset. Jumlah citra yang tidak seimbang seperti ini akan menghasilkan model yang didominasi oleh salah satu kelas dengan jumlah citra terbanyak. Harry Pratt [29] dan Gabriel Garcia [22] menggunakan pembobotan setiap kelas sesuai dengan jumlah citra dari masing-masing kelas untuk mengatasi jumlah kelas yang tidak seimbang. Pembobotan kelas juga digunakan pada penelitian ini. Bobot masing-masing kelas dihitung dengan cara [30]:

$$
w_{j}=\frac{\sum_{i}^{k} n_{i}}{c \times n_{j}}
$$

Di mana:

- $\sum_{i}^{k} n_{i}$ adalah jumlah seluruh citra dari $k$ kelas

- $w_{j}$ adalah bobot kelas ke $-j$

- $n_{j}$ adalah jumlah citra dari kelas ke - $j$

- $c$ adalah jumlah kelas dari dataset

Dengan perhitungan tersebut diperoleh bobot dari setiap kelas yang dapat dilihat pada Tabel IV.

TABEL IV

BOBOT DARI SETIAP KELAS DR

\begin{tabular}{|c|c|c|}
\hline Tingkat DR & Jumlah citra & Bobot kelas \\
\hline 0 & 1,796 & 0.389532 \\
\hline 1 & 338 & 2.069822 \\
\hline 2 & 921 & 0.759609 \\
\hline 3 & 173 & 4.043931 \\
\hline 4 & 270 & 2.591111 \\
\hline Total & $\mathbf{3 , 4 9 8}$ & \\
\hline
\end{tabular}

\section{2) Mengubah Ukuran Citra}

Teknik mengubah ukuran citra mengadopsi teknik yang digunakan Ben Graham [25]. Citra diubah ukurannya sehingga memiliki radius pixel yang sama. Radius pixel yang digunakan adalah 300 pixel. Berikut ini adalah potongan kode dengan bahasa python: 
Algoritma 1: Mengubah ukuran citra dengan radius yang ditentukan

Input: img dan scale $=300$

Output: s (faktor skala citra)

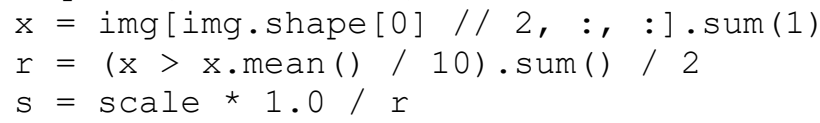

Di mana:

- x menghitung nilai citra pada baris tengah dan dijumlahkan pada sumbu channel.

- $r$ menghitung radius fundus retina. Operasi x > $\mathrm{x}$.mean () / 10 memberikan nilai True untuk area retina dan $\mathrm{False}$ untuk area warna hitam.

- s mengkonversi nilai $r$ dengan radius pixel pilihan yaitu 300 pixel. Nilai skalar s digunakan sebagai faktor skala untuk mengubah ukuran citra.

Teknik mengubah ukuran citra dengan menggunakan faktor skala akan tetap memperhatikan aspek rasio dari setiap citra. Hasil dari citra yang sudah diubah ukurannya dapat dilihat pada Gambar 9. Citra yang diubah ukurannya ini menjadi dasar untuk setiap preprocessing berikutnya karena citra yang ukurannya lebih kecil mengurangi beban komputasi.
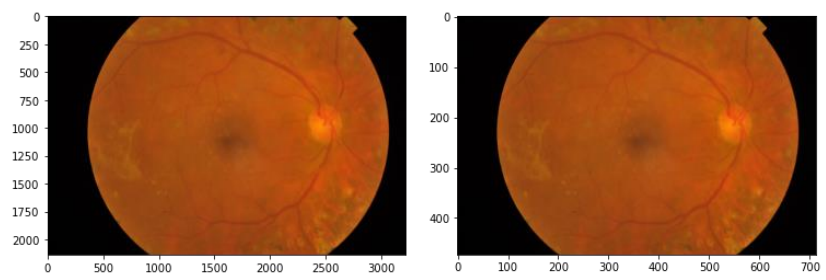

Gambar 9. Citra sebelum dan setelah ukuran diubah

\section{3) Preprocessing Ben Graham}

Terdapat tiga tahapan preprocessing yang dilakukan oleh Ben Graham [25], yaitu:

- Mengubah ukuran citra dengan metode rescale yang sudah dibahas pada bagian 2) Mengubah Ukuran Citra.

- Mengurangi warna citra dengan warna rata-rata lokal, lalu dipetakan ke 50\% abu-abu

- Memotong citra secara melingkar menjadi 90\% dari radius pixel yang diberikan untuk menghilangkan "boundary effects."

Citra dikurangi warna rata-rata lokal dengan menggunakan persamaan klasik linear unsharp masking yang diberikan dengan:

$$
y(n, m)=\lambda \times x(n, m)+(-\lambda) \times g(n, m)+128
$$

Di mana:

- $y(n, m)$ adalah citra output

- $x(n, m)$ adalah citra input,

- $g(n, m)$ adalah citra yang diburamkan dengan Gaussian blur.
- $\lambda(\lambda=4)$ adalah faktor skala yang mengontrol peningkatan kontras citra output

Nilai $g(n, m)$ diperoleh dari:

$$
g(n, m)=G(n, m, \sigma) * x(n, m)
$$

Di mana:

- $G(n, m, \sigma)$ adalah gaussian filter dengan $\sigma=10$

- * adalah operator convolution

- $x(n, m)$ adalah citra input
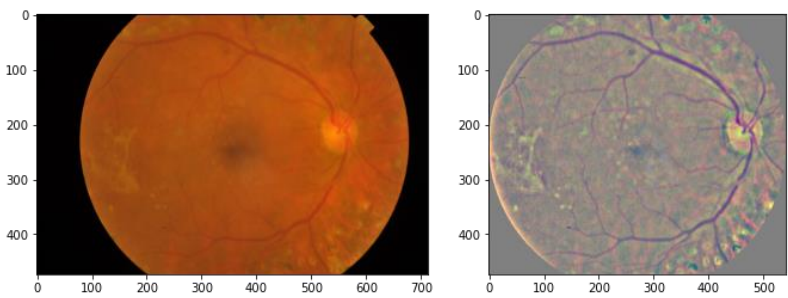

Gambar 10. Preprocessing Ben Graham

Hasil dari preprocessing Ben Graham dapat dilihat pada Gambar 10. Gambar sebelah kiri merupakan gambar input, yang belum melewati preprocessing Ben Graham dan gambar sebelah kanan adalah citra yang sudah melewati preprocessing Ben Graham. Tampak bahwa warna citra setelah preprocessing lebih homogen.

\section{4) Preprocessing Nakhon}

Preprocessing Nakhon [26] diawali dengan mengubah ukuran citra dan memotong margin hitam pada citra. Margin hitam dipotong dengan mencari baris dan kolom pada citra yang memiliki setidaknya satu pixel di sepanjang baris dan kolom yang lebih besar dari nilai threshold yang ditentukan (threshold $=7$ ) sehingga membentuk bounding box pada area fundus retina saja [31]. Setelah margin hitam dibuang, proses selanjutnya serupa dengan preprocessing yang dilakukan oleh Ben Graham, namun Nakhon tidak membuang "boundary effect". Nakhon memotong setiap citra secara melingkar, sehingga citra fundus retina memiliki bentuk yang sama. Gambar 11 menunjukan citra input dan citra output dari preprocessing Nakhon. Bisa dilihat pada citra output, bentuk retina dipotong dengan melingkar sempurna dan memiliki "boundary effect"
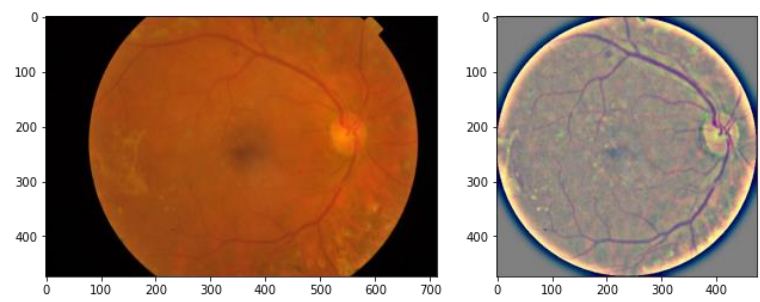

Gambar 11. Preprocessing Nakhon Ratchasima 


\section{5) Preprocessing Ramasubramanian}

Ramasubramanian dan Selvaperumal [27] mengusulkan teknik preprocessing dengan mengambil green channel dari citra RGB karena green channel memiliki informasi paling banyak dan menunjukkan diskriminasi antara gejala klinis dengan warna latar belakang. Mula-mula citra diambil channel hijau saja lalu margin hitam dipotong. Median filter digunakan untuk menghilangkan salt and pepper noise pada citra sambil mempertahankan garis tepi pada citra fundus retina. Ukuran kernel median filter yang digunakan adalah $3 \times 3$.

Setelah noise dihilangkan, citra ditingkatkan dengan menggunakan Contrast Limited Adaptive Histogram Equalization (CLAHE). CLAHE membagi citra input ke dalam delapan wilayah kontekstual lalu histogram equalization diterapkan pada wilayah tersebut. Dengan CLAHE, fitur tersembunyi seperti exudates, microaneurysms, fovea, blood vessel akan lebih terlihat. Hasil preprocessing usulan Ramasubramanian dapat dilihat pada Gambar 12. Citra hasil preprocessing Ramasubramanian disimpan sebagai citra tiga channel yang terdiri atas channel hijau semua (Green, Green, Green / G, G, G). Dari kiri ke kanan: citra sebelum preprocessing, citra yang sudah melewati preprocessing Ramasubramanian dan dilipatkan menjadi tiga channel.
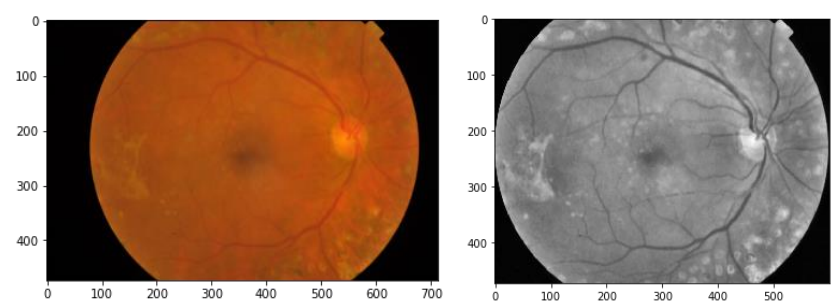

Gambar 12. Preprocessing Ramasubramanian dan Selvaperumal

\section{6) Preprocessing Enhanced Green}

Preprocessing enhanced green menerapkan dua teknik processing citra, yaitu CLAHE yang diikuti dengan unsharp masking. Citra yang digunakan pada preprocessing ini adalah citra dari channel hijau saja seperti yang diusulkan oleh Ramasubramanian. Mula-mula kontras citra ditingkatkan dengan CLAHE. CLAHE membagi citra input ke dalam beberapa wilayah kontekstual dengan kernel berukuran $8 \times 8$ lalu histogram equalization diterapkan pada wilayah tersebut. Menurut Ramasubramanian [27], CLAHE menonjolkan fitur tersembunyi seperti exudates, microaneurysms, fovea, blood vessel.

Setelah kontras citra diperbaiki, citra ditajamkan dengan unsharp masking. Unsharp masking telah lama digunakan dalam industri percetakan dan penerbitan untuk menajamkan citra dengan mengurangi citra asli dengan citra yang sudah diburamkan (unsharp). Proses unsharp masking terdiri dari beberapa langkah [32]:

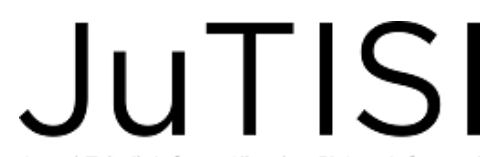

- Citra asli diburamkan. Teknik untuk memburamkan citra menggunakan Gaussian blur seperti yang diusulkan oleh Ben Graham.

- Kurangi citra asli dengan citra yang sudah diburamkan. Proses ini membentuk mask.

- Tambahkan citra asli dengan mask yang terbentuk

Unsharp masking bisa diberikan dengan persamaan [33]:

$$
y(n, m)=\alpha \times x(n, m)+\beta \times g(n, m)
$$

Di mana:

- $y(n, m)$ adalah citra output

- $x(n, m)$ adalah citra input

- $g(n, m)$ adalah citra yang diburamkan dengan Gaussian blur.

- $\alpha$ adalah koefisien citra asli. $\alpha$ ditetapkan dengan nilai 4 mengikuti koefisien yang dipilih oleh Ben Graham.

- $\beta$ adalah $1-\alpha$

Nilai $g(n, m)$ diperoleh dari:

$$
g(n, m)=G(n, m, \sigma) * x(n, m)
$$

Di mana:

- $G(n, m, \sigma)$ adalah gaussian filter dengan $\sigma=10$

- $x(n, m)$ adalah citra input

- * adalah operator convolution

Citra hasil preprocessing enhanced green disimpan sebagai citra tiga channel yang terdiri atas channel hijau semua (G, G, G). Hasil preprocessing enhanced green dapat dilihat pada Gambar 13. Citra sebelah kiri merupakan citra input. Citra sebelah kanan merupakan citra output dari preprocessing enhanced green yang dilipatkan menjadi tiga channel. Dapat dilihat pada gambar tersebut, objek pada gambar berupa titik atau garis lebih tajam.
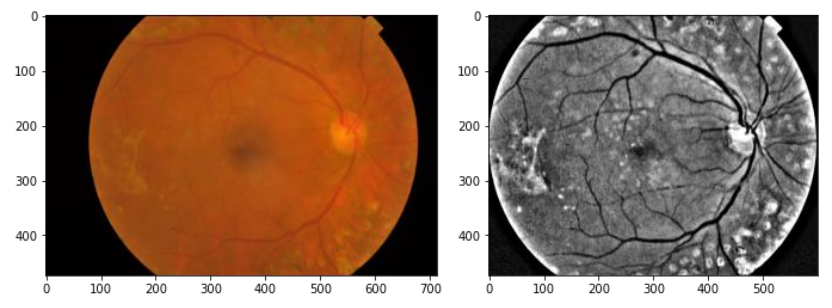

Gambar 13. Preprocessing enhanced green

\section{Augmentasi}

Augmentasi citra adalah strategi yang memungkinkan praktisi untuk meningkatkan keragaman data yang tersedia untuk training model, tanpa benar-benar mengumpulkan data baru [34]. Dengan augmentasi, model menerima input citra yang sudah ditransformasi sehingga citra input lebih beragam. Tujuan augmentasi adalah agar model tidak melihat citra yang sama dua kali selama training. Augmentasi membantu model terpapar aspek yang lebih banyak dari data 
dan menghasilkan model yang lebih mengeneralisir [35]. Teknik augmentasi yang dipakai adalah:

- Rotasi citra: $10^{\circ}$

- Pergeseran citra pada sumbu $x$ dan sumbu $y$

- Distorsi citra dengan shear sebesar 0.1

- Zoom: $90 \%$ - $110 \%$

- Flipping horizontal dan vertikal

Augmentasi ini diterapkan untuk citra training saja, sedangkan untuk citra validation tidak dilakukan augmentasi. Citra yang diaugmentasi dapat dilihat pada Gambar 14

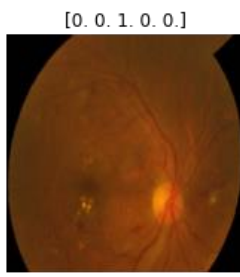

[1. 0.0 .0 .0$. . 0.$]$

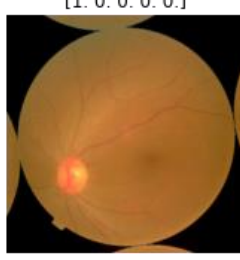

Gambar 14. Citra training dengan augmentasi

\section{E. Training Model}

Training model menggunakan library Keras, yang merupakan high level API dari platform deep learning Tensorflow. Pada Keras sudah terdapat berbagai model pretrained yang di-training dengan dataset ImageNet, termasuk model dengan arsitektur Inception v3. Perangkat keras yang digunakan adalah CPU Core2Quad Q9550, RAM 8GB, GPU GTX 1070 8GB. Adapun Hyperparameter yang dipakai untuk training model dapat dilihat pada Tabel V.

TABEL V

HYPERPARAMETER YANG DIPAKAI SETIAP TRAINING MODEL

\begin{tabular}{|l|l|l|}
\hline No & \multicolumn{1}{|c|}{ Hyperparameter } & \multicolumn{1}{c|}{ Nilai } \\
\hline 1 & Ukuran citra & $299 \times 299 \times 3$ \\
\hline 2 & Batch Size & 32 \\
\hline 3 & Optimisasi & ADAM \\
\hline 4 & Loss function & Categorical cross entropy \\
\hline
\end{tabular}

\begin{tabular}{|l|l|l|}
\hline \multicolumn{1}{|c|}{ No } & \multicolumn{1}{|c|}{ Hyperparameter } & \multicolumn{1}{c|}{ Nilai } \\
\hline 5 & Metrik & $\begin{array}{l}\text { Accuracy }(\text { Acc }), \text { precision, } \\
\text { recall, AUC }\end{array}$ \\
\hline 6 & Learning rate classifier & $1 e^{-4}$ \\
\hline 7 & Epoch classifier & 50 \\
\hline 8 & Learning rate fine tuning & $2 e^{-6}$ \\
\hline 9 & Epoch fine tuning & 50 \\
\hline 10 & Weight decay & 0.01 \\
\hline
\end{tabular}

Training model terbagi menjadi dua skema sesuai dengan rumusan masalah yang diberikan, yaitu:

- Training model untuk menguji pengaruh preprocessing terhadap performa model.

- Training model untuk menguji banyaknya blok Inception v3 yang perlu di-fine tuning.

1) Pengujian Pengaruh Preprocessing

Training model ini dilakukan dengan pendekatan transfer learning. Bagian convolution dari Inception v3 menggunakan bobot pretrained dari dataset ImageNet. Sedangkan bobot bagian classifier diinisialisasi dengan Glorot Uniform [36]. Training model dilakukan pada bagian classifier terlebih dahulu lalu diikuti dengan fine tuning dua blok Inception v3 [10]. Training classifier dilakukan sebanyak 50 epoch dengan learning rate $1 e^{-4}$. Sewaktu training classifier, bobot pada bagian convolution dibekukan sehingga tidak diperbaharui. Fine tuning dilakukan sebanyak 50 epoch dengan learning rate $2 e^{-6}$.

Dataset dibagi menjadi $80 \%$ untuk training dan $20 \%$ untuk validation dengan metode 5 -fold cross validation. Hasil dari 5-fold cross validation ini dirata-ratakan sebagai nilai akhir akurasi model. Dataset yang dipakai pada training ini adalah 1) citra yang sudah diubah ukurannya, 2) citra dengan preprocessing Ben Graham, 3) citra dengan preprocessing Nakhon Ratchasima, 4) citra dengan preprocessing Ramasubramanian, dan 5) citra dengan preprocessing enhanced green.

\section{2) Fine Tuning $n$ Blok Inception v3}

Training model ini menggunakan dataset yang diubah ukurannya. Mula-mula training dilakukan pada bagian classifier, yang diikuti dengan fine tuning terhadap blok Inception v3 seperti yang diilustrasikan pada Gambar 16 . Fine tuning dilakukan sebanyak $n$ blok, $n=[1,2,3, \ldots, 10]$ dan semua lapisan. Dataset dibagi menjadi dua, yaitu $80 \%$ train dan $20 \%$ validation dengan teknik holdout, bukan dengan 5-fold cross validation. 


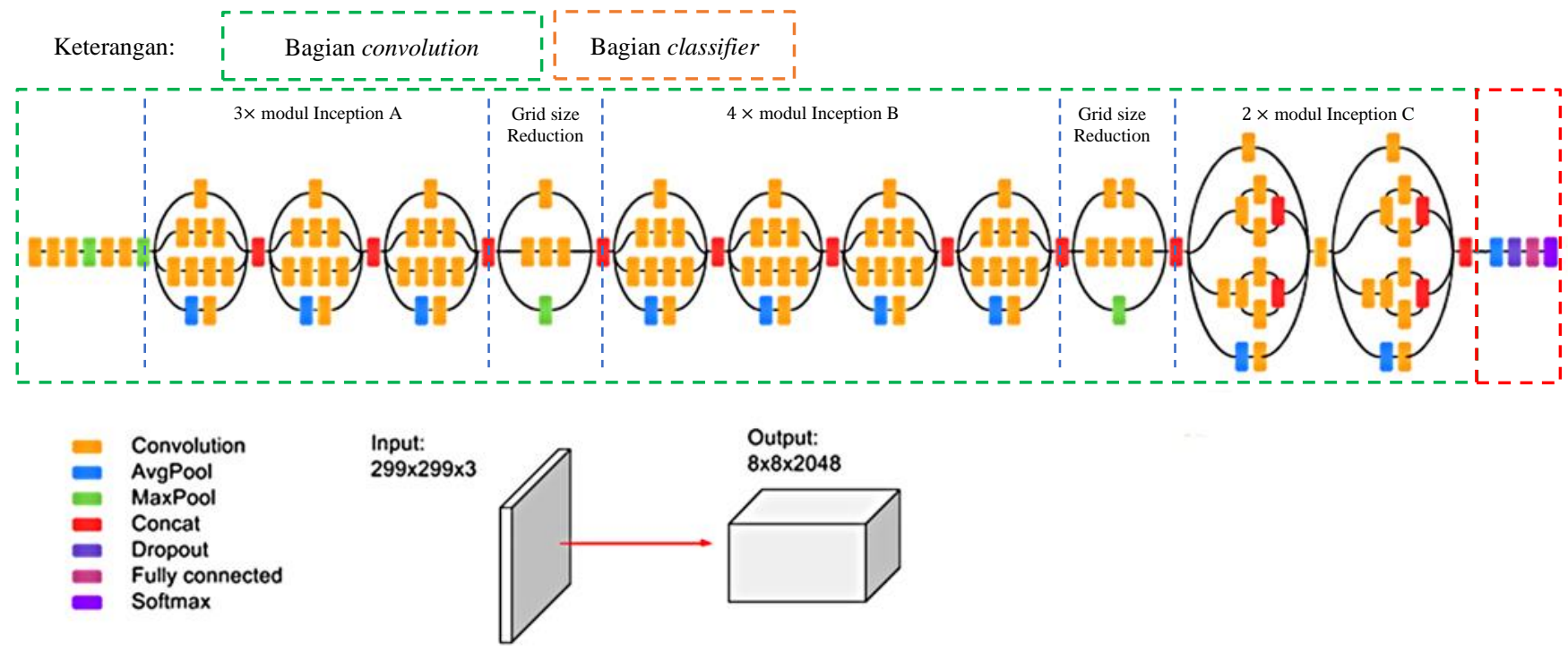

Gambar 15. Bagian umum arsitektur CNN [37]

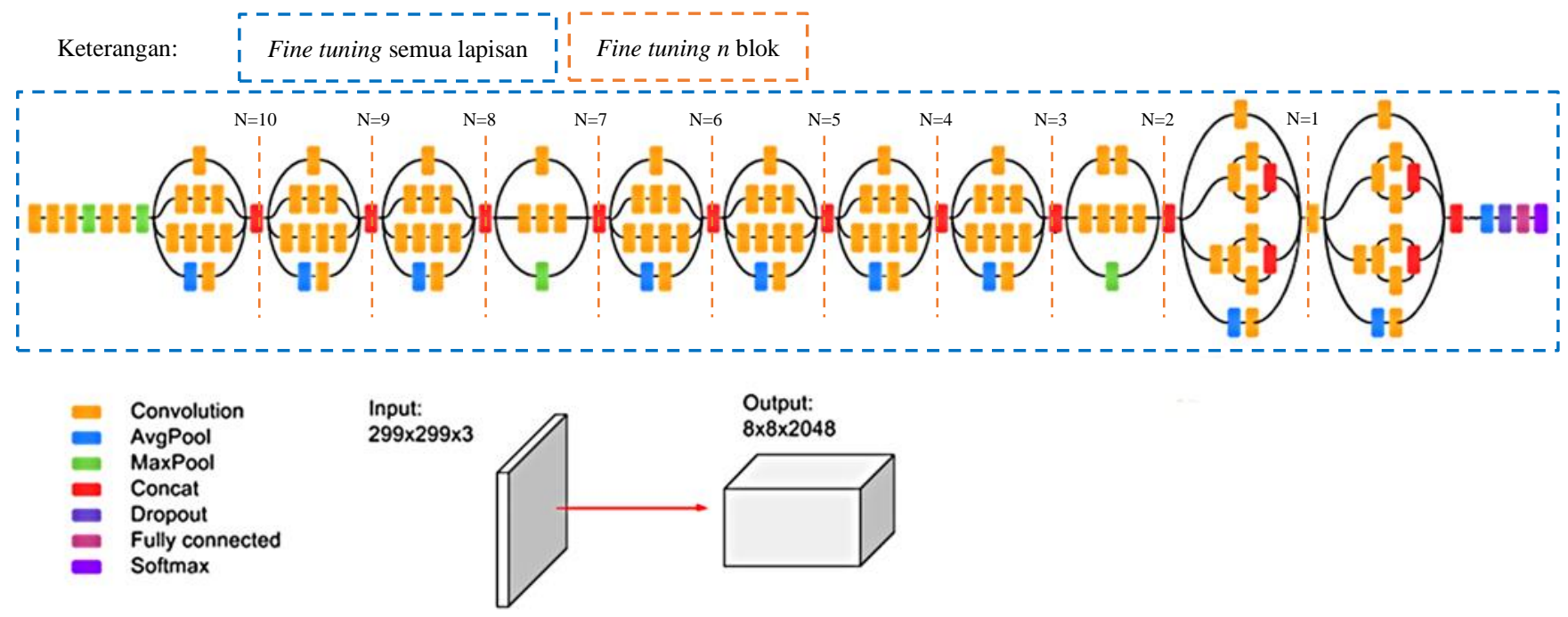

Gambar 16. Fine tuning $n$ blok Inception v3 [37]

\section{HASIL DAN PEMBAHASAN}

Hasil training untuk melihat pengaruh preprocessing terhadap performa model akan fokus pada akurasi model. Training dengan lima kondisi dataset menghasilkan lima model, yaitu:

- Model rescale_png adalah model yang di-training dengan dataset asli yang diubah ukurannya.

- Model ben_graham adalah model yang di-training dengan dataset dengan preprocessing Ben Graham.

- Model nakhon adalah model yang di-training dengan dataset dengan preprocessing Nakhon.
- Model ramasubramanian adalah model yang ditraining dengan dataset dengan preprocessing Ramasubramanian.

- Model enhanced_green adalah model yang di-training dengan dataset dengan preprocessing enhanced green. Demikian juga untuk training model fine tuning $n$ blok Inception v3. Hasil training ini melihat akurasi yang diberikan oleh setiap model dengan jumlah blok yang di-fine tuning berbeda.

\section{A. Pengaruh Preprocessing - Training Classifier}


Hasil training bagian classifier dari lima kondisi dataset dapat dilihat pada Tabel VI. Nilai ini diukur dari dataset validation setelah training sebanyak 50 epoch selesai dan merupakan rata-rata dari 5-fold cross validation. Pada tabel tersebut dapat dilihat bahwa model enhanced_green memberikan hasil yang paling baik dengan nilai: akurasi $76.10 \%$, precision $81.92 \%$, recall $69.90 \%$ dan AUC $95.12 \%$. Model kedua terbaik diberikan oleh model ramasubramanian dengan nilai akurasi $74.10 \%$. Model rescale_png menempati posisi ketiga, sedangkan model ben_graham dan nakhon menempati posisi keempat dan kelima.

TABEL VI

METRIK HASIL TRAINING CLASSIFIER

\begin{tabular}{|c|c|c|c|c|c|}
\hline Model & Loss & Acc & $\begin{array}{c}\text { Precisi } \\
\text { on }\end{array}$ & Recall & AUC \\
\hline $\begin{array}{c}\text { rescale_ } \\
\text { png }\end{array}$ & 1.94 & $73.78 \%$ & $80.70 \%$ & $66.81 \%$ & $94.53 \%$ \\
\hline $\begin{array}{c}\text { ben_gra } \\
\text { ham }\end{array}$ & 2.09 & $72.73 \%$ & $79.52 \%$ & $65.09 \%$ & $94.16 \%$ \\
\hline nakhon & 2.02 & $69.10 \%$ & $78.70 \%$ & $60.09 \%$ & $93.05 \%$ \\
\hline $\begin{array}{c}\text { ramasub } \\
\text { ramania } \\
n\end{array}$ & 1.91 & $74.10 \%$ & $81.26 \%$ & $67.41 \%$ & $94.92 \%$ \\
\hline $\begin{array}{c}\text { enhance } \\
\text { d_green }\end{array}$ & 1.93 & $76.10 \%$ & $81.92 \%$ & $69.90 \%$ & $95.12 \%$ \\
\hline
\end{tabular}

F1-score untuk setiap kelas DR dari lima model ini dapat dilihat pada Tabel VII. Pada tabel tersebut kelas 0 memberikan nilai paling tinggi. Hal ini dikarenakan kelas 0 memiliki jumlah citra paling banyak. Sedangkan kelas 3 memberikan nilai paling kecil karena kelas 3 memiliki jumlah citra paling sedikit meskipun pembobotan kelas selama training sudah diberikan. Dari tabel ini juga dapat dilihat bahwa F1-score tertinggi dari setiap kelas DR diberikan oleh model yang berbeda. DR kelas 0 diberikan oleh model ramasubramanian, DR kelas 1 diberikan oleh model rescale_png, DR kelas 2 dan 4 diberikan oleh model enhanced_green. DR kelas 3 diberikan oleh model ramasburamanian dan enhanced_green.

TABEL VII

F1-SCORE TRAINING CLASSIFIER

\begin{tabular}{|c|c|c|c|c|c|}
\hline $\begin{array}{c}\text { DR } \\
\text { Level }\end{array}$ & $\begin{array}{c}\text { rescale_ } \\
\text { png }\end{array}$ & graham & nakhon & $\begin{array}{c}\text { ramasu } \\
\text { braman } \\
\text { ian }\end{array}$ & $\begin{array}{c}\text { enhanc } \\
\text { ed_gree } \\
\text { n }\end{array}$ \\
\hline 0 & $95.6 \%$ & $95.2 \%$ & $95.0 \%$ & $\mathbf{9 6 . 4 \%}$ & $95.8 \%$ \\
\hline 1 & $\mathbf{5 2 . 6 \%}$ & $46.2 \%$ & $46.2 \%$ & $49.6 \%$ & $46.2 \%$ \\
\hline 2 & $59.6 \%$ & $56.2 \%$ & $48.6 \%$ & $57.6 \%$ & $\mathbf{6 4 . 6 \%}$ \\
\hline 3 & $36.6 \%$ & $31.4 \%$ & $34.4 \%$ & $\mathbf{3 7 . 6 \%}$ & $\mathbf{3 7 . 6} \%$ \\
\hline 4 & $38.2 \%$ & $42.2 \%$ & $30.4 \%$ & $41.4 \%$ & $\mathbf{4 7 . 4 \%}$ \\
\hline
\end{tabular}

B. Pengaruh Preprocessing - Fine Tuning
Setelah training bagian classifier selesai, fine tuning dilakukan sebanyak dua blok Inception v3. Hasil fine tuning dari setiap model dapat dilihat pada Tabel VIII. Nilai ini diukur dari dataset validation setelah training sebanyak 50 epoch selesai dan merupakan rata-rata dari 5-fold cross validation. Pada tabel tersebut tampak bahwa model enhanced_green memberikan hasil yang paling baik dengan nilai: akurasi $78.79 \%$, precision $82.97 \%$, recall $74.64 \%$, dan AUC 95.81\%. Model rescale_png menempati posisi kedua dengan nilai akurasi $77.27 \%$ yang diikut model ramasubramanian di posisi ketiga dengan nilai akurasi $76.73 \%$. Sedangkan model ben_graham dan nakhon menempati posisi keempat dan kelima.

TABEL VIII

METRIK HASIL FINE TUNING

\begin{tabular}{|c|c|c|c|c|c|}
\hline Model & Loss & Acc & $\begin{array}{c}\text { Precisi } \\
\text { on }\end{array}$ & Recall & AUC \\
\hline $\begin{array}{c}\text { rescale_ } \\
\text { png }\end{array}$ & 1.83 & $77.27 \%$ & $80.79 \%$ & $72.41 \%$ & $95.32 \%$ \\
\hline $\begin{array}{c}\text { ben_gra } \\
\text { ham }\end{array}$ & 1.98 & $75.59 \%$ & $80.35 \%$ & $70.04 \%$ & $94.97 \%$ \\
\hline nakhon & 1.89 & $72.30 \%$ & $79.56 \%$ & $65.72 \%$ & $94.25 \%$ \\
\hline $\begin{array}{c}\text { ramasub } \\
\text { ramania } \\
n\end{array}$ & 1.81 & $76.73 \%$ & $81.17 \%$ & $72.44 \%$ & $95.62 \%$ \\
\hline $\begin{array}{c}\text { enhance } \\
\text { d_green }\end{array}$ & 1.83 & $78.79 \%$ & $82.97 \%$ & $74.64 \%$ & $95.81 \%$ \\
\hline
\end{tabular}

F1-score untuk setiap kelas DR dari lima model ini dapat dilihat pada Tabel IX. Pada tabel tersebut kelas 0 memberikan nilai paling tinggi. Hal ini dikarenakan kelas 0 memiliki jumlah citra paling banyak. Sedangkan kelas 3 memberikan nilai paling kecil karena kelas 3 memiliki jumlah citra paling sedikit meskipun pembobotan kelas selama training sudah diberikan. Dari tabel ini juga dapat dilihat bahwa F1-score tertinggi dari setiap kelas DR diberikan oleh model yang berbeda. DR kelas 0 , 1, dan 3 diberikan oleh model ramasubramanian. DR kelas 2 dan 4 diberikan oleh model enhanced_green.

TABEL IX

F1-SCORE FINE TUNING

\begin{tabular}{|c|c|c|c|c|c|}
\hline $\begin{array}{c}\text { DR } \\
\text { Level }\end{array}$ & $\begin{array}{c}\text { rescale_ } \\
\text { png }\end{array}$ & graham & nakhon & $\begin{array}{c}\text { ramasu } \\
\text { braman } \\
\text { ian }\end{array}$ & $\begin{array}{c}\text { enhanc } \\
\text { ed_gree } \\
\text { n }\end{array}$ \\
\hline 0 & $96.2 \%$ & $96.6 \%$ & $96.2 \%$ & $\mathbf{9 7 . 4 \%}$ & $96.4 \%$ \\
\hline 1 & $55.2 \%$ & $53.0 \%$ & $51.0 \%$ & $\mathbf{5 5 . 4 \%}$ & $52.2 \%$ \\
\hline 2 & $67.2 \%$ & $60.6 \%$ & $55.0 \%$ & $62.4 \%$ & $\mathbf{6 8 . 8 \%}$ \\
\hline 3 & $41.4 \%$ & $36.6 \%$ & $35.6 \%$ & $\mathbf{4 2 . 0 \%}$ & $41.4 \%$ \\
\hline 4 & $43.4 \%$ & $44.8 \%$ & $33.4 \%$ & $44.8 \%$ & $\mathbf{5 2 . 0 \%}$ \\
\hline
\end{tabular}

C. Fine Tuning $n$ blok inception 
Hasil training $n$ blok Inception $\mathrm{v} 3$ bisa dilihat pada Tabel $X$. Nilai pada tabel tersebut diukur pada dataset validation setelah training sebanyak 50 epoch selesai. Gambar 17 adalah visualisasi Tabel $\mathrm{X}$ dalam bentuk grafik batang untuk nilai akurasi. Sumbu $x$ pada Gambar 17 adalah jumlah blok Inception yang di-training dan sumbu $y$ adalah nilai akurasi model. Jika mengacu pada grafik ini, fine tuning memberikan hasil terbaik jika dilakukan sebanyak sembilan blok Inception. Tampak juga pada grafik bahwa fine tuning dari lapisan manapun memberikan benefit terhadap performa model dengan rentang kenaikan akurasi antara $1.71 \%$ sampai $5.14 \%$.

TABEL X

PERFORMA MODEL YANG DI-TRAINING SEBANYAK $N$ BLOK INCEPTION V3

\begin{tabular}{|c|c|c|c|c|c|}
\hline Blok & Loss & Acc & $\begin{array}{c}\text { Precisi } \\
\text { on }\end{array}$ & Recall & AUC \\
\hline classifier & 1.95 & $73.86 \%$ & $80.78 \%$ & $67.86 \%$ & $94.21 \%$ \\
\hline 1 & 1.86 & $75.86 \%$ & $79.84 \%$ & $69.57 \%$ & $94.73 \%$ \\
\hline 2 & 1.86 & $75.57 \%$ & $79.62 \%$ & $72.00 \%$ & $94.97 \%$ \\
\hline 3 & 1.84 & $76.14 \%$ & $79.68 \%$ & $71.71 \%$ & $95.16 \%$ \\
\hline 4 & 1.84 & $77.14 \%$ & $81.79 \%$ & $73.14 \%$ & $95.24 \%$ \\
\hline 5 & 1.82 & $77.86 \%$ & $81.79 \%$ & $74.43 \%$ & $95.41 \%$ \\
\hline 6 & 1.82 & $77.71 \%$ & $81.36 \%$ & $73.57 \%$ & $95.53 \%$ \\
\hline 7 & 1.81 & $77.71 \%$ & $81.49 \%$ & $74.86 \%$ & $95.64 \%$ \\
\hline 8 & 1.81 & $78.86 \%$ & $81.64 \%$ & $75.57 \%$ & $95.54 \%$ \\
\hline 9 & 1.81 & $79.00 \%$ & $81.41 \%$ & $74.43 \%$ & $95.59 \%$ \\
\hline 10 & 1.82 & $77.57 \%$ & $81.40 \%$ & $75.00 \%$ & $95.49 \%$ \\
\hline $\begin{array}{c}\text { Semua } \\
\text { lapisan }\end{array}$ & 1.81 & $78.86 \%$ & $81.85 \%$ & $76.00 \%$ & $95.74 \%$ \\
\hline
\end{tabular}

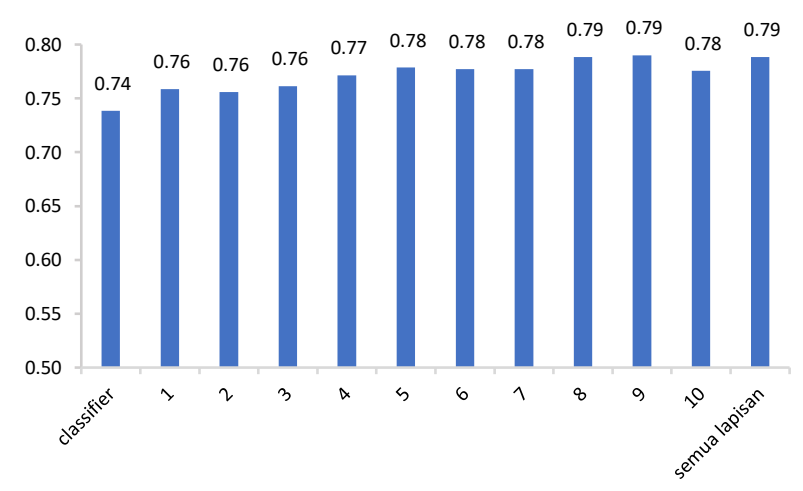

Gambar 17. Akurasi model dengan fine tuning $n$ blok Inception v3

\section{SIMPULAN}

Dalam penelitian ini didapati bahwa tidak semua preprocessing memberikan hasil yang baik. Dari empat preprocessing yang dilakukan, yaitu Graham, Nakhon, Ramasubramanian dan enhanced green, didapati bahwa enhanced green memberikan performa yang paling baik. Model enhanced_green memberikan nilai akurasi $76.10 \%$ pada training classifier dan nilai akurasi $78.79 \%$ setelah fine tuning. Selisih akurasi model antara enhance green dengan model tanpa preprocessing adalah $1.52 \%$. Preprocessing enhanced green mengambil channel hijau dari citra fundus retina lalu dilakukan image enhancement dengan CLAHE untuk memperbaiki kontras citra dan diikuti dengan unsharp masking untuk menajamkan citra. Citra hasil preprocessing enhanced green disimpan sebagai citra tiga channel di mana setiap channel-nya adalah channel hijau.

Fine tuning $n$ blok Inception yang dilakukan pada penelitian ini menunjukkan bahwa fine tuning bisa dilakukan mulai dari blok Inception v3 mana pun dan tetap memberikan benefit terhadap performa model. Fine tuning memberikan rentang kenaikan akurasi antara $1.71 \%$ sampai $5.14 \%$. Jika dilihat dari hasil percobaan, fine tuning sebanyak sembilan blok Inception v3 memberikan hasil terbaik dengan nilai akurasi $79.0 \%$

Berdasarkan hasil temuan dari eksplorasi yang telah dilakukan, terdapat sejumlah eksplorasi lanjutan yang dapat dilakukan. Penelitian selanjutnya dapat melakukan hyperparameter tuning dan menggunakan beberapa teknik optimasi training model. Hyperparameter yang bisa dituning seperti learning rate, ukuran batch, nilai probabilitas dropout, dan nilai weight decay. Teknik optimasi yang bisa diimplementasikan saat training model seperti learning rate decay, reduce learning rate on plateau, ataupun early stopping. Arsitektur CNN yang dipilih bisa menggunakan arsitektur yang lebih baru seperti MobileNet, Inception v4, ataupun EfficientNet. Arsitektur classifier pun bisa dieksplorasi dengan menambahkan hidden layer atau pun hidden unit.

Penelitian berikutnya bisa menggunakan ukuran citra yang lebih besar, misalnya $598 \times 598 \times 3$. Memperbesar ukuran citra training diharapkan dapat memberikan akurasi model yang lebih baik. Preprocessing yang digunakan dalam penelitian ini juga bisa digunakan pada dataset lain untuk melihat robustness pengaruh setiap preprocessing terhadap performa model.

Kesulitan terbesar dalam penelitian ini adalah interpretasi model. Model dipandang sebagai black box yang menerima input dan mengeluarkan output. Output berupa performa model yang diukur pada penelitian ini. Jika penelitian dilakukan bersama dengan seorang ophthalmologist maka interpretasi model bisa lebih baik untuk melihat pengaruh preprocessing terhadap fitur pada citra fundus retina.

\section{DAFTAR PUSTAKA}

[1] M. Sazzad Hossen, A. A. Reza, dan M. C. Mishu, “An automated model using deep convolutional neural network for retinal image classification to detect diabetic retinopathy," dalam ACM International Conference Proceeding Series, 2020, hlm. 1-8, doi: 10.1145/3377049.3377067.

[2] N. Asiri, M. Hussain, F. Al Adel, dan N. Alzaidi, "Deep learning based computer-aided diagnosis systems for diabetic retinopathy: A 
survey," Artif. Intell. Med., vol. 99, no. July, hlm. 101701, 2019, doi: 10.1016/j.artmed.2019.07.009.

[3] Y. W. Chen, T. Y. Wu, W. H. Wong, dan C. Y. Lee, "Diabetic Retinopathy Detection Based on Deep Convolutional Neural Networks," ICASSP IEEE Int. Conf. Acoust. Speech Signal Process. Proc., vol. 2018-April, hlm. 1030-1034, 2018, doi: 10.1109/ICASSP.2018.8461427.

[4] A. Krizhevsky, I. Sutskever, dan G. E. Hinton, "ImageNet classification with deep convolutional neural networks," Commun. $A C M$, vol. 60, no. 6, hlm. 84-90, Mei 2017, doi: 10.1145/3065386.

[5] N. Tajbakhsh $d k k$., "Convolutional Neural Networks for Medical Image Analysis: Full Training or Fine Tuning?," IEEE Trans. Med. Imaging, vol. 35, no. 5, hlm. 1299-1312, Mei 2016, doi: 10.1109/TMI.2016.2535302.

[6] "ImageNet." [Online]. Tersedia pada: http://image-net.org/aboutstats. [Diakses: 13-Okt-2020]

[7] J. Yosinski, J. Clune, Y. Bengio, dan H. Lipson, "How transferable are features in deep neural networks?," Adv. Neural Inf. Process. Syst., vol. 4, no. January, hlm. 3320-3328, 2014

[8] M. A. Bravo dan P. A. Arbelaez, "Automatic Diabetic Retinopathy Classification," hlm. 10.

[9] C. Lian, Y. Liang, R. Kang, dan Y. Xiang, "Deep convolutional neural networks for diabetic retinopathy classification," ACM Int. Conf. Proceeding Ser., no. c, hlm. 68-72, Jun 2018, doi: 10.1145/3239576.3239589.

[10] S. Mohammadian, A. Karsaz, dan Y. M. Roshan, "Comparative Study of Fine-Tuning of Pre-Trained Convolutional Neural Networks for Diabetic Retinopathy Screening," dalam 2017 24th National and 2nd International Iranian Conference on Biomedical Engineering (ICBME), Tehran, 2017, hlm. 1-6, doi: 10.1109/ICBME.2017.8430269 [Online]. Tersedia pada: https://ieeexplore.iee.org/document/8430269/. [Diakses: 25-Jun2020]

[11] C. Szegedy, V. Vanhoucke, S. Ioffe, J. Shlens, dan Z. Wojna, "Rethinking the Inception Architecture for Computer Vision," dalam 2016 IEEE Conference on Computer Vision and Pattern Recognition (CVPR), Las Vegas, NV, USA, 2016, hlm. 2818-2826, doi: 10.1109/CVPR.2016.308 [Online]. Tersedia pada: http://ieeexplore.iee.org/document/7780677/. [Diakses: 25-Jun2020]

[12] Asia Pacific Tele-Ophthalmology Society, "APTOS 2019 Blindness Detection dataset," APTOS 2019, 2019. .

[13] I. Goodfellow, Y. Bengio, dan A. Courville, Deep learning. Cambridge, Massachusetts: The MIT Press, 2016.

[14] G. Currie, K. E. Hawk, E. Rohren, A. Vial, dan R. Klein, "Machine Learning and Deep Learning in Medical Imaging: Intelligent Imaging," J. Med. Imaging Radiat. Sci., vol. 50, no. 4, hlm. 477-487, 2019, doi: 10.1016/j.jmir.2019.09.005.

[15] C. Szegedy dkk., "Going deeper with convolutions," dalam Proceedings of the IEEE Computer Society Conference on Computer Vision and Pattern Recognition, 2015, vol. 07-12-June, no. 8, hlm. 19, doi: 10.1109/CVPR.2015.7298594.

[16] X. Wang, Y. Lu, Y. Wang, dan W. B. Chen, "Diabetic retinopathy stage classification using convolutional neural networks," Proc. 2018 IEEE 19th Int. Conf. Inf. Reuse Integr. Data Sci. IRI 2018, hlm. 465-471, 2018, doi: 10.1109/IRI.2018.00074.

[17] S.-H. Tsang, "Review: Inception-v3 - 1st Runner Up (Image Classification) in ILSVRC 2015," Medium, 23-Mar-2019. [Online]. Tersedia pada: https://sh-tsang.medium.com/review-inception-v31st-runner-up-image-classification-in-ilsvrc-2015-17915421f77c. [Diakses: 11-Jan-2021]

[18] "vision.learner | fastai." [Online]. Tersedia pada: https://fastai1.fast.ai/vision.learner.html\#cnn_learner. [Diakses: 04Jan-2021]

[19] "Fitting Batch Norm into a neural network," Coursera. [Online]. Tersedia pada: https://www.coursera.org/learn/deep-neural-
network/lecture/RN8bN/fitting-batch-norm-into-a-neural-network. [Diakses: 30-Des-2020]

[20] Z. Gao, J. Li, J. Guo, Y. Chen, Z. Yi, dan J. Zhong, "Diagnosis of Diabetic Retinopathy Using Deep Neural Networks," IEEE Access, vol. 7, hlm. 3360-3370, 2019, doi: 10.1109/ACCESS.2018.2888639.

[21] Dr. A. Rosebrock, Deep Learning for Computer Vision with Python Starter Bundle, First printing., vol. 1, 3 vol. PYIMAGESEARCH, 2017.

[22] G. García, J. Gallardo, A. Mauricio, J. López, dan C. Del Carpio, "Detection of Diabetic Retinopathy Based on a Convolutional Neural Network Using Retinal Fundus Images," dalam Artificial Neural Networks and Machine Learning - ICANN 2017, vol. 10614, A. Lintas, S. Rovetta, P. F. M. J. Verschure, dan A. E. P. Villa, Ed. Cham Springer International Publishing, 2017, hlm. 635-642 [Online]. Tersedia pada: http://link.springer.com/10.1007/978-3-319-68612 7 72. [Diakses: 05-Des-2020]

[23] M. T. Hagos dan S. Kant, "Transfer Learning based Detection of Diabetic Retinopathy from Small Dataset," 2019.

[24] "Image hashing with OpenCV and Python - PyImageSearch." [Online]. Tersedia https://www.pyimagesearch.com/2017/11/27/image-hashingopencv-python/. [Diakses: 31-Des-2020]

[25] B. Graham, "Kaggle Diabetic Retinopathy Detection competition report," hlm. 9 .

[26] "APTOS : Eye Preprocessing in Diabetic Retinopathy." [Online]. Tersedia pada: https://kaggle.com/ratthachat/aptos-eyepreprocessing-in-diabetic-retinopathy. [Diakses: 19-Des-2020]

[27] B. Ramasubramanian dan S. Selvaperumal, "A comprehensive review on various preprocessing methods in detecting diabetic retinopathy,' dalam 2016 International Conference on Communication and Signal Processing (ICCSP), Melmaruvathur, Tamilnadu, India, 2016, hlm. 0642-0646, doi: 10.1109/ICCSP.2016.7754220 [Online]. Tersedia pada: http://ieeexplore.ieee.org/document/7754220/. [Diakses: 05Des-2020]

[28] Aravind Eye Care System, "4th Asia Pacific Tele-Ophthalmology Society (APTOS) Symposium,” APTOS 2019, 2019.

[29] H. Pratt, F. Coenen, D. M. Broadbent, S. P. Harding, dan Y. Zheng, "Convolutional Neural Networks for Diabetic Retinopathy,' Procedia Comput. Sci., vol. 90, no. July, hlm. 200-205, 2016, doi: 10.1016/j.procs.2016.07.014.

[30] "scikit-learn/scikit-learn," GitHub. [Online]. Tersedia pada: https://github.com/scikit-learn/scikit-learn. [Diakses: 02-Jan-2021]

[31] "python - Crop black border of image using NumPy," Code Review Stack Exchange. [Online]. Tersedia pada: https://codereview.stackexchange.com/questions/132914/crop-blackborder-of-image-using-numpy. [Diakses: 13-Jan-2021]

[32] R. C. Gonzalez dan R. E. Woods, Digital image processing, 3. ed., internat. ed. Upper Saddle River, NJ: Pearson, 2010

[33] "OpenCV: Operations on arrays." [Online]. Tersedia pada: https://docs.opencv.org/master/d2/de8/group_core_array.html\#gaf afb2513349db3bcff51f54ee5592a19. [Diakses: 12-Jan-2021]

[34] J. Sanjaya dan M. Ayub, "Augmentasi Data Pengenalan Citra Mobil Menggunakan Pendekatan Random Crop, Rotate, dan Mixup," J. Tek Inform. Dan Sist. Inf., vol. 6, no. 2, Agu 2020, doi: 10.28932/jutisi.v6i2.2688. [Online]. Tersedia pada: https://journal.maranatha.edu/index.php/jutisi/article/view/2688. [Diakses: 05-Des-2020]

[35] F. Chollet, Deep learning with Python. Shelter Island, New York: Manning Publications Co, 2018

[36] "tf.keras.initializers.GlorotUniform | TensorFlow Core v2.4.0." [Online]. Tersedia pada: https:/www.tensorflow.org/api_docs/python/tf/keras/initializers/Glo rotUniform. [Diakses: 01-Jan-2021]

[37] "Advanced Guide to Inception v3 on Cloud TPU," Google Cloud. [Online]. Tersedia pada: https://cloud.google.com/tpu/docs/inception-v3-advanced. [Diakses: 11-Jan-2021] 